International Journal of Social and Educational Sciences Volume 2, Issue 4 December 2015

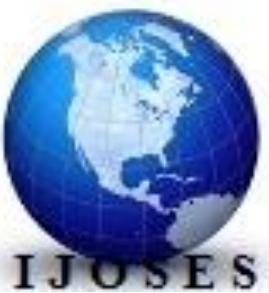

Uluslararası Sosyal ve Ĕ̈itim

Bilimleri Dergisi

Cilt 2, Sayı 4

Aralık 2015

ISSN: 2148- 8673

\title{
PEDAGOGICAL APPROACHES OF ELEMENTARY TEACHERS FOR PRIMARY REFUGEE CHILDREN
}

\author{
İLKOKULA GIDDEN MÜLTECİ ÇOCUKLARA YÖNELIK SINIF ÖĞRETMENLERININ \\ PEDAGOJIK YAKLAŞIMLARI
}

\author{
Ali Ramazan ER* \& Nida BAYINDIR*
}

\begin{abstract}
Throughout history, people have had to leave their homelands because of wars, firefights, violence and oppression. The fact that people are made to leave their countries makes the refugee issue a serious problem worldwide. Refugees experience many problems in social, economic and cultural spheres. Children, however, are the most affected ones. Inadequacy of the education they get or a total deprivation of that will make them confront some more significant and serious problems in coming years. The aim of this study is to specify the pedagogical approaches of elementary teachers for primary refugee students. General scanning model in quantitative research design was used in this research. This research was conducted to 182 elementary teachers working in İzmir city center in 2015-2016 education periods. The data was collected by one dimensional survey developed by researchers. Internal validity index of the survey consisting 25 items was calculated as 0,95. For the data analysis, $\mathrm{t}$ test, frequency and percentage were used. According to the findings of this study, one third of the elementary teachers have stated that they have refugee children in their classes and the majority of the elementary teachers, $(\% 74,7)$ have declared that they don't have any knowledge regarding the education of refugee children. Also it is stated that the majority of the elementary teachers that participate in this study $(\% 83,0)$ believe that refugee children cannot carry out their education without any problem. This reveals that teachers of refugee children in İzmir are ineligible. Thereby, it is suggested that in-service training activities regarding the education of refugee children be arranged for elementary teachers.
\end{abstract}

Keywords: Elementary Teachers, Refugee Children and Education,

*(Dr.); Milli Eğitim Bakanlığı, aliramazaner38@gmail.com

** (Doç. Dr.); Dumlupınar Üniversitesi Eğitim Fakültesi, nida.bayindir@dpu.edu.tr 


\section{PEDAGOGICAL APPROACHES OF ELEMENTARY TEACHERS FOR PRIMARY REFUGEE CHILDREN}

Öz

Uzun yıllar insanlar zulüm, silahlı çatışma ve şiddet olayları yüzünden yurtlarını terk etmek zorunda kalmışlardır. İnsanların zorla yerlerinden ayrılmaları bütün dünyada mülteciliği ciddi bir sorun haline getirmiştir. Mülteciler, ekonomik, sosyal, kültürel vb. birçok alanda sorunlar yaşamaktadır. Mülteciler içinde ise en çok etkilen çocuklardır. Onların eğitim süreçlerinin yetersiz veya bu süreçten tamamen mahrum kalması, ilerleyen yıllarda daha önemli ve ciddi bir sorunla da karşı karşıya kalmalarına neden olmaktadır. Araştırmanın amacı, ilkokula giden mülteci çocuklara yönelik sınıf öğretmenlerinin pedagojik yaklaşımlarını belirlemektir. Araştırmada nicel araştırma deseninde genel tarama modeli kullanılmıştır. Araştırma, 2015-16 eğitim öğretim yılında İzmir il merkezinde görev yapan 182 sınıf öğretmenine yapılmıştır. Veri toplama aracı olarak araştırmacılar tarafından tek boyutlu olarak geliştirilen bir anketle veriler toplanmıştır. 25 maddeden oluşan anketin iç tutarlık katsayısı 0,95 olarak hesaplanmıştır. Verilerin çözümlenmesinde yüzde, frekans ve t testi kullanılmıştır. Araştırma bulgularına göre, sınıf öğretmenlerinin yaklaşık 1/3'ünün sınıfında mülteci çocuk bulunduğu belirlenirken öğretmenlerin büyük bir çoğunluğu $(\% 74,7)$ mülteci çocukların eğitimlerine ilişkin herhangi bir eğitimleri olmadığ yönünde görüş bildirmişlerdir. Ayrıca araştırmada öğretmenlerin büyük bir çoğunluğunun $(\% 83,0)$ mülteci çocukların eğitimlerini sorunsuz bir şekilde gerçekleştiremeyeceklerine inandıkları belirlenmiştir. Bu durum İzmir ilinde ilkokula giden mülteci çocukların öğretmenlerinin bu konuda yetersiz olduğunu ortaya çıkarmaktadır. Buna göre sınıf öğretmenlerine mülteci çocukların eğitimine yönelik hizmet içi eğitim kurslarının düzenlenmesi önerilmektedir.

Anahtar Kelimeler: Sınıf Öğretmeni, Mülteci Çocuklar ve Eğitim

\section{Introduction}

Education has a significant role in the construction of a nation. Trained and qualified man power is the most important element of wealth for a nation. The exploration of this power and the discovery of self-potential of individuals will be the utmost investment for the future of that nation. Countries make a great effort for education to raise citizens who are efficient and have the consciousness, sense of responsibility and respect for the rules, laws and society. Nevertheless, education despite its vitality is the first humanistic activity that is suspended in cases of wars, migrations and natural disasters. There are many studies that reveal and present the effects of migration on urbanization, agriculture, crime, terror, social structure and primarily on education (Arı, 2007; Brinker-Gabler and Smith, 1997); Çelik, 2007; Erdoğmuş, 1989; Türkyılmaz, Çay, and Avşar, 1998; Yalçın, 2004; Zeybekoğlu and Johansan, 2003).

Though the notion of migration dates back to centuries before Christian era, it takes different dimensions with the growth of some countries as a result of the economy, developing industry, and technological advancements; as a result, new terms are coined like refugee and asylum seeker. 


\subsection{Immigration and Its Stance in Turkey}

Immigration is the syndrome of the search for a new country when a group of people implicitly or explicitly are forced to leave their community and culture (Penrose, 2003). There are various reasons that put Turkey in a crucial point regarding the issue of immigration which comes out with the effects of social and political phenomenon such as the geographical position that centers Turkey for Asia, Africa and Europe especially for transportation route and the war and unrest experiences of the neighbors of Turkey (Ribas-Mateos, 2005).

As per article 28 of Declaration of the Rights of the Child and article 22 of ESKHS and MHSS, it is essential that the children of refugee and immigrant families benefit from their rights of education without any exposition to discrimination. The fact that they have left their countries doesn't take this necessary responsibility of the state away. Additionally, the right of education should never be ignored as the article 42 of the Constitution suggests. Though there isn't any provision for refugees, the right of education in the Constitution includes them as well in a humanistic manner (IHAD, 2013).

In the instruction part of a practice in 2006 for refugees and immigrants' education assessment notes the following provision: "As the article 2 of 222 Educational Law no suggests the compulsory education includes children with 06-14 group of age. Therefore, it is mandatory that all children in that group of age receive education, no matter what status they are in. There should be coordination of Directorate of National Education with non-governmental organizations to enroll the children of refugee and immigrant families in schools".

It is the prolonging process of refugees' taking refuge that makes the education problem explicit and also necessitates such researches and studies. It is observed that refugee children face such difficulties in the country that they take refuge: discrimination, hardships in making friends, experiencing language problems, communication problems among teachers, students and parents and curriculum problems. These are seen as obstacles that hinder children's social integrity. The fact that they lack an equivalency certificate that indicates their education status in their country limits their chance to maintain their education significantly (İHAD, 2013).

The unrest that began in March 2011 in Syria with democracy and reform wishes has exposed Turkey one of the biggest migration moves in history. As a result of the events in Syria, the first group of 250 immigrants entered Turkey on April 29, 2011 and the entrances have been going on in parallel with the increase of violent events. As a side of International Refugee Law and according to International Law Practices, Turkey enabled "temporary protection" status for Syrian refugees as a result of the open door policy. Thus, Syrian refugees will be kept as "guests" in Turkey and all their 


\section{PEDAGOGICAL APPROACHES OF ELEMENTARY TEACHERS FOR PRIMARY REFUGEE CHILDREN}

needs are tried to be met until the unrest in their country ends (Grand National Assembly of Turkey Human Rights Investigation Commission, 2012).

One of the most affected areas by Syrian conflict is the education process of youths and adolescents. Because of the closed schools since March 2011 when the upheavals started, there was an unschooled time for Syrian children even before entering to Turkey. It is the exceeding foreseen number of refugees and the time that have attached greater significance of educational needs in this context. It is seen that what Turkey did by meeting educational and all other needs of accepted Syrians into refugee camps with greater rates has been applauded with UN, and many other international institutions (UN higher board of commissioners UNICEF, 2013).

According to the UNICEF data, \% 73 of Syrian children in Turkey cannot have the access to schools. Although all of the children in camps have an access to schools, $10 \%$ of children living in city centers can go to schools (Karaca and Dinçer, 2013). Even if situation is slightly better in camps, overall schooling remains 15-20\% (Erdoğan, 2014). A small number of children living out of camps can get education. The first reason for that is that resources and facilities cannot be supplied as needed. A second effective factor is that Syrian families direct their children not into schools but to workplaces (Oytun and Gündoğar, 2015).

This research carries importance since it aims to define educational problems of primary-school-age refugee children in Turkey, and also to define teachers' attitudes toward these problems and to offer solution. That's why; it is aimed to bring suggestions to the educational needs of primary school age refugee children through the requests of elementary teachers.

\section{Method}

General survey model in quantitative research design was used in this research which aims to define elementary teachers' pedagogical attitudes toward primary school refugee children. Scanning model is a sort of model which defines existing condition, and demonstrates information about variables (Karasar, 2009).

\subsection{Data Collection Method and Data Analysis}

This research was conducted to 182 elementary teachers working in İzmir city center since the number of primary schools that include refugee students is very high in 20152016 education periods. The data was collected by one dimensional survey developed by researchers. The survey, to adapt refugee children to their existing classes- was 5 point Likers Scale and, for content validity of the survey, suggestions of teachers and masters were asked and applied. Internal validity index of the survey consisting 25 items was calculated as 0,95 . This significance shows the efficacy of used survey's high measuring power. For the data analysis, a $t$ test was used to see whether they have refugee children in their classes, whether they took any pre-education for refugee 
children and whether refugee children's education processed with no problems. Research is confined with participants, survey and statistical analysis.

\section{Findings}

In this chapter, the data obtained from the measuring instruments that are used in this study and statistics regarding these data are presented. The issue of refugee children in classrooms, the knowledge levels of teachers regarding refugee children's education and the findings concerning refugee children's carrying out their education with no problems are all indicated through tables.

Table 1 indicates whether there are refugee children in the classes of the elementary teachers that participate in the study or not.

Table 1: Refugee Children in Classrooms

\begin{tabular}{ccccc}
\hline Answers & Fr. & $\%$ & $\mathrm{~m}$ & ss \\
\hline Yes & 60 & 33,0 & & \\
No & 122 & 67,0 & 1,67 & 0,47 \\
Total & 182 & 100,0 & & \\
\hline
\end{tabular}

Table 1 indicates that \% 33 of the elementary teachers that participate in the study stated that they have refugee children in their classrooms whereas the rest of the teachers, \% 67, stated that they don't have any in their classrooms. In other words, one third of teachers have refugee children in their classrooms. Table 2 shows the knowledge level of the teachers that participate in the study regarding the education of the refugee children.

Table 2: Teachers' Knowledge Level Regarding Refugee Children's Education Status

\begin{tabular}{ccccc}
\hline Answers & Fr. & $\%$ & m & ss \\
\hline Yes & 46 & 25,3 & 1,75 & 0,43 \\
No & 136 & 74,7 & & \\
Total & 182 & 100,0 & & \\
\hline
\end{tabular}

Table 2 demonstrates that $\% 74,7$ of the elementary teachers that participate in the study expressed that they don't have any knowledge about the education status of refugee children while $\% 25,3$ of the elementary teachers conveyed that they have the knowledge. Table 3 shows the education status of refugee children according to teachers that participate in the study.

Table 3: Education Status of Refugee Children as Reported by Teachers

\begin{tabular}{lllll}
\hline Answers & Fr. & $\%$ & $\mathrm{~m}$ & ss \\
\hline
\end{tabular}




\begin{tabular}{ccccc}
\hline Yes & 31 & 17,0 & 1,83 & 0,37 \\
No & 151 & 83,0 & & \\
Total & 182 & 100 & & \\
\hline
\end{tabular}

Table 3 shows that \% 83 of the teachers think that refugee children can't maintain their education problem-free. In other words, a small number of teachers think that refugee children can maintain their education free of problems. Table 4 demonstrates the knowledge of the teachers regarding the different situations of refugee children coping with a problem-free education.

Table 4: Refugee Children's Statuses of Maintaining Their Education in a Hassle Free Way

\begin{tabular}{|c|c|c|c|c|c|c|c|}
\hline Article Name & $\mathbf{R}$ & $\mathbf{n}$ & Av. & SS & $\mathrm{T}$ & Sd & $\mathbf{p}$ \\
\hline \multirow{4}{*}{$\begin{array}{c}\begin{array}{c}\text { I have } \\
\text { knowledge } \\
\text { about post- }\end{array} \\
\frac{\text { traumatic stress }}{\text { disorder }}\end{array}$} & Yes & 31 & 3,13 & 1,0 & 3,22 & 180 & 0,01 \\
\hline & \multirow{3}{*}{ No } & \multirow{3}{*}{151} & \multirow{3}{*}{2,46} & 2 & & & \\
\hline & & & & 1,0 & & & \\
\hline & & & & 6 & & & \\
\hline \multirow{4}{*}{$\begin{array}{l}\text { I don't have } \\
\text { difficulty in } \\
\text { communication }\end{array}$} & \multirow{4}{*}{$\begin{array}{l}\text { Yes } \\
\text { No }\end{array}$} & \multirow{4}{*}{$\begin{array}{l}31 \\
151\end{array}$} & \multirow{4}{*}{$\begin{array}{l}3,39 \\
2,58\end{array}$} & 1,0 & 3,77 & 180 & 0,01 \\
\hline & & & & 5 & & & \\
\hline & & & & 1,0 & & & \\
\hline & & & & 9 & & & \\
\hline \multirow{4}{*}{$\begin{array}{l}\text { I can easily } \\
\text { carry out the } \\
\text { normal } \\
\text { curriculum }\end{array}$} & \multirow{4}{*}{$\begin{array}{l}\text { Yes } \\
\text { No }\end{array}$} & \multirow{4}{*}{$\begin{array}{l}31 \\
151\end{array}$} & \multirow{4}{*}{$\begin{array}{l}3,26 \\
2,40\end{array}$} & 1,1 & 3,87 & & 0,01 \\
\hline & & & & 8 & & & \\
\hline & & & & 1,1 & & & \\
\hline & & & & 1 & & & \\
\hline \multirow{4}{*}{$\begin{array}{l}\text { I can overcome } \\
\text { the language } \\
\text { obstacle }\end{array}$} & \multirow{4}{*}{$\begin{array}{l}\text { Yes } \\
\text { No }\end{array}$} & 31 & 3,32 & 0,9 & 4,51 & & 0,01 \\
\hline & & \multirow{3}{*}{151} & \multirow[t]{3}{*}{2,44} & 7 & & & \\
\hline & & & & 0,9 & & & \\
\hline & & & & 9 & & & \\
\hline \multirow{4}{*}{$\begin{array}{l}\text { I can find } \\
\text { translator when } \\
\text { required }\end{array}$} & Yes & 31 & 3,10 & 1,1 & 4,29 & & 0,01 \\
\hline & \multirow[t]{3}{*}{ No } & \multirow[t]{3}{*}{151} & \multirow[t]{3}{*}{2,17} & 6 & & & \\
\hline & & & & 1,0 & & & \\
\hline & & & & 7 & & & \\
\hline
\end{tabular}

\section{$\mathbf{P}<0,01$}


As the figures in table 4 indicate a meaningful difference is detected at a level of $p<0,01$ for the benefit of the teachers who have the knowledge about the posttraumatic disorder, who think that they don't have any difficulty in communication, who express that they can handle the language obstacle and easily carry out the normal curriculum and finally who state that they can find a translator when needed. Consequently, this is either because teachers approach refugee children's education with an equivalent way of other students in classrooms or because they are unaware of the problems that they might confront.

The facts that refugee children aren't able to speak Turkish and also that teachers don't have knowledge about the posttraumatic disorder cause communication problems. Additionally, it is observed that teachers experience difficulties in applying the curriculum since they claim that the present curriculum isn't suitable for the refugee children.

\section{Discussion, Conclusion and Suggestions}

The war in Syria is a tragedy known by everybody. Millions of people had to leave their country because of that war. These people have encountered a lot of problems in places to which they migrated. One of these problems is education. In this research which was conducted to determine the pedagogical approaches of elementary teachers concerning especially primary school migrant children, the following results are deduced:

There are immigrant children in one third of classrooms of elementary teachers who are included in the research. It is emphasized in the 2011 report of BMMYK that the refugee condition is getting better in Turkey. The 17 percent increase with the children between the ages of 6-17 who go to school comparing to the year 2010 is the demonstration of improvement for the refugee right and conditions (UNHCR, 2012). This situation shows that the immigrant children cannot be ignored and the problems of education should be taken into consideration. Most of the teachers $(74,7 \%)$ in the research stated that they don't have any formation concerning the education of immigrant children. This, as a result, shows elementary teachers don't know how to treat immigrant children. In other words, it has been revealed that the elementary teachers should have the formation for the education of these children. It has been emphasized in another research that both teachers and authorities that are responsible for the education of the Syrian refugee children aren't experts in their fields. The Turkish teachers that are teaching immigrant children have suggested the continuation of the seminars with the occupational sufficiency (Arabac1 vd. 2014).

Most of the teachers $(83,0 \%)$ think that immigrant children cannot continue their education without problems. Despite these indications, it has been reached to a point that there are teachers who think they are knowledgeable about the stress disorder and will not have communication problem and will apply the usual curriculum to migrant children by overcoming the language handicap. The self confidence of the teachers can 


\section{PEDAGOGICAL APPROACHES OF ELEMENTARY TEACHERS FOR PRIMARY REFUGEE CHILDREN}

be the reason for their unawareness of the possible future problems and for their considering the immigrant children's education equal to usual classrooms. Since they don't have the knowledge about the stress disorder with children after the trauma, it becomes clear that teachers experience hardships applying the usual curriculum to the immigrant students.

Teachers reported that they had experienced communication problems due to language differences of refugee students. Researchers in other studies identified that immigrant students experienced difficulty in their education for the difference of language, pronunciation and accents (Gray At all, 1996; Hornberger, 1998; Parlakkaya, 2010).

The teachers stated that they have no knowledge about post-traumatic stress disorder that occurs in children. Other researches show that the war profoundly affects people's lives. The reflection of violent behavior by the children who were exposed to violence in war is a situation that may be encountered. Especially Syrian teachers stated that children experienced war trauma and this affected their lives. Children that undergo trauma experiences stand as a long-term problem for the community (Arabac1 At all, 2014).

Teachers reported that they had difficulty in implementing the existing curriculum to student refugees. In other research carried out, all of the issues raised by Turkey and Syria are the lack of a curriculum plan and program for students from refugee status in Syria. Due to lack of the programs, it has been identified that there is no association of application between the administration and the teachers (Balkanl1, 2014). Güllüpınar (2010), in his study regarding the causes of the failure of children in Germany, concluded that the problem stems from individuals and family reasons inasmuch as structural factors such as lack of intercultural curriculum and so on. In addition, in other studies, it is emphasized that there is an urgent need to prepare a program for students with war trauma, taking into account individual and cultural conditions (Barenbaum At all, 2004; Gupta and Zimmer, 2008).

According to these conclusions, it can be suggested as follows:

1. It is suggested that in-service training activities regarding the education of refugee children be arranged for elementary teachers.

2. It is suggested that refugee children receive help from psychologists and guidance counselors in order to get used to the education, the classroom and the compeers.

3. On top of all, the fact that refugee children learn Turkish should be dwelt on. In this regard, it is suggested that schools provide training programs of Turkish for immigrant children. 


\section{REFERENCES}

Arabaci, İ. B., Başar, M., Akan, D. and Goksoy, S. (2014). An Analysis about Educational Problems in Camps in which Syrian Refugees Stay: Condition Analysis International J. Soc. Sci. \& Education 2014 4(3).

Ari, F. A. (2007). Türkiye'de Yabancı Issçiler: Uluslararası Göç, Isşgücü ve Nüfus Hareketleri. İstanbul: Derin Yayınları.

Balkanli, R. (2014). Göçün Öğrencinin Eğitim Yaşantısı Üzerindeki Etkisi. Yayınlanmamış doktora tezi. Dumlupınar Üniversitesi Eğitim Bilimleri Enstitüsü. Kütahya

Barenbaum, J., Ruckhin, V. and Schwab-Stone, M. (2004). The psychological aspect of children; attending exposed to war: Practice and policy initiatives, Journal of child Psychological and Psychiatry 45(1) 41-62

Brinker Gabler, G. and Smith, S. (1997). Writing New Identities: Gender, Nation, and Immigration in Contemporary Europe. Minneapolis: University of Minnesota.

Celik, F. (2007). Türkiye'de İç Göçler: 1980-2000. Sosyal Bilimler Enstitüsü Dergisi, 22(1),87-109.

Dincer, O. B., Karaca, S. and Yavuz, H. (2013). Göçün İkinci Yılında Suriyeli Savaş Mağdurlar. Analist dergisi, 25, Ankara.

Erdogan, M. M. (2014). Türkiye'deki Suriyeliler: Toplumsal Kabul ve Uyum Araştırması. Hacettepe Üniversitesi Göç ve Siyaset Araştırmaları Merkezi, Ankara

Erdogmuş, Z. (1989). Türkiye'de Kırdan Kente Göçün Sosyal Temelleri. Fırat Üniversitesi Sosyal Bilimler Dergisi, 3(2), 97-108.

Genel Gündem Haber Sitesi, UNHCR'nin Türkiye değerlendirmeleri, “BM Mülteciler Yüksek Komiserliği (UNHCR), Türkiye'ye mültecilere sağladıkları korumadan dolay1 minnettarlık duyuyor." 27 Ekim 2013, http://genelgundem.com/haberler/658.aspx, 30.10.2013.

Gupta. L. and ZIMMER, C. (2008). Psychological interventions for war affected children Sierra Leone, British Journal of Psychiatry

Gray, M. J., Rolph, E. and Melamid, E. (1996). Immigration and Higher Education: Institutional Responses to Changing Demographics, Santa Monica, CA: Rand.

Güllüpinar, F. (2010). Almanya'da Türk Göçmenlerin Çocuklarının Bölünmüş Kaderleri ve Eğitimde Başarısızlıklarının Yapısal Nedenleri: Entegrasyon Aşağı mı Yukarı mı? Eğitim Bilim Toplum 8 (31) 65-87

Hornberger, N. H. (1998). Language policy, Language Education, Language Rights: Indigenous, Immigrant, and International Perspectives. Language in Society, 27, 439-458. 
İHAD İnsan Hakları Araştırmaları Derneği (2013)., 2012 Türkiye İltica Hakkı İzleme Raporu, Ankara (http://www.ihad.org.tr/file/reports/2013/2012 iltica.pdf; 21.05.2014.

Karasar, N. (2009). Bilimsel Araştırma Yöntemi. Ankara: Nobel Yayınları.

Oytun, O. ve Gündogar, S. S. (2015). Suriyeli Sığınmacıların Türkiye'ye Etkileri Raporu,. ORSAM- TESEV Rapor No: 195, Ankara.

Penrose, J. (2003). “The UN Convention Relating To The Status Of Refugee: The Case For and Against Reform", Forced Migration and The Contemporary World: Challenges To The International System, Bolesta, Andrzej (ed.),(Bialystok: Wydawnictwo I Drukarnia PPHU).

Ribas-Mateos, N. (2005). Migration, Welfare, and Borders, The Mediterranean in the Age of Globalization. New Brunswick, NJ and London:Transaction Publishers.

Parlakkaya, Ç. (2010). Göçe Bağlı Olarak İlköğretim Okullarında Yaşanan İstenmeyen Öğrenci Davranışlarına İlişkin Öğretmen ve Yönetici Görüşleri. Yayımlanmamış yüksek lisans tezi. Sakarya Üniversitesi Sosyal Bilimler Enstitüsü, Sakarya.

TBMM İnsan Haklarını İnceleme Komisyonu (2012), “Ülkemize Sığınan Suriye Vatandaşlarının Barındıkları Çadır kentler Hakkında inceleme Raporu", s.3-8, http://www.tbmm.gov.tr/komisyon/insanhaklari/belge/ulkemize_siginan_ suriye_vatandaslarinin_barindiklari_cadirkentler_hakkinda_inceleme_raporu_3.p df., 02 Ekim 2013.

Türkyilmaz, A., Çay, A. ve Avşar, B. Z. (1998). Doğu ve Güneydoğu Anadolu'dan Terör Nedeniyle Göç Eden Ailelerin Sorunları. Ankara: T.C. Başbakanlık Aile Araştırma Kurumu Başkanlığı.

UNHCR. (2012). Global Reports of 2011, 1 June 2012, http://www.unhcr.org, 1 Şubat 2013

Yalçin, C. (2004). Göc Sosyolojisi. Ankara: Anı Yayıncılık.

Zeybekoğlu, E. and Johansson, B. (2003). Migration and Labour in Europe: Views fromTurkey and Sweden. İstanbul: Marmara University Research Center for International Relations (MURCIR); Swedish National Institute for Working Life. IX, 306. 


\section{Ali Ramazan ER \& Nida BAYINDIR}

\section{Appendix 1 - Survey}

Pedagogical Approaches of Elementary Teachers for Primary Refugee Students

1. Do you have refugee children in your classes?

Yes ( ) No ( )

2. Do you have any knowledge about the education of refugee children?

Yes ( ) No ( )

3. Can you handle the education of refugee children without any problem?

Yes ( ) No ( )

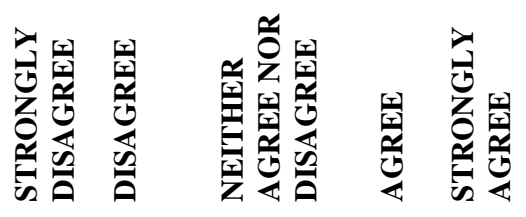

1. I evaluate the risk factors.

2. I have the knowledge and ability to remove risk factors.

3. I have the knowledge about posttraumatic disorder.

4. I don't have difficulty in communication

5. I can provide a safe communication for children of

the same age

6. I can easily apply the normal curriculum

7. I can enhance enthusiasm for school

8. I can handle the conflicts and problems of the children with others.

9. I can ensure their attendance

10. I can have an academic communication with their families

11. I can transfer these to the electronic information system of the school.

12. I provide them to benefit from school facilities

like other children

13. I can handle the language obstacle

14. I have the knowledge for fair approaches

15. I can find a translator when needed.

16. I have the knowledge to teach Turkish to foreign

students.

17. I have projects and activities to socialize them with their peers

18. I have plans to prevent discrimination

19. I can provide them a constructive and an improving class atmosphere.

20. I can prepare extra homework and practices

21 . I can provide stationery equipment that they need to benefit from educational services

22. I can spare time for them

23. I can revise the subjects for them

24. I can organize and present activities that they can appreciate

25. I can have the evaluation peculiar to them

Other 